\title{
Rancang Bangun Aplikasi Pemesanan Menu Makanan Restoran Berbasis Android
}

\author{
Jos Forman Tompoh ${ }^{1)}$, Steven R. Sentinuwo ${ }^{2)}$, Alicia A. E. Sinsuw ${ }^{3)}$ \\ Teknik Informatika Universitas Sam Ratulangi Manado \\ Email : 110216120@ student.unsrat.ac.id, steven@unsrat.ac.id, alicia.sinsuw@unsrat.ac.id
}

\begin{abstract}
Penelitian ini bertujuan untuk merancang dan membangun suatu aplikasi pemesanan menu makanan restoran untuk membantu pihak restoran dalam menangani pemesanan menu makanan. Dengan menggunakan web-service aplikasi pemesanan menu di sisi pelanggan berbasis android (client) dapat terintegrasi dengan aplikasi web-admin di pihak restoran untuk mengatur pemesanan (server). Dalam rancang bangun aplikasi ini menggunakan metode RAD (Rapid Application Development) yang terdiri dari tahapan analisa persyaratan, analisis modeling, desain modeling, dan fase konstruksi. Dan aplikasi ini hanya untuk melayani sistem pemesanan menu restoran.
\end{abstract}

Kata kunci: web-service, client-server, metode RAD, restoran.

\section{PENDAHULUAN}

\section{I.1. Latar Belakang}

Pemanfaatan teknologi Smartphone pada berbagai aspek kini telah dirasakan dampaknya, tanpa terkecuali sampai pada restoran-restoran yang ingin memanfaatkan teknologi ini demi kepuasan pelanggan dan keuntungan pihak restoran. Manusia pada umumnya menginginkan segala sesuatu dapat dengan mudah dikerjakan, begitu pula dengan pelanggan restoran yang ingin memesan menu dengan mudah dalam artian tidak rumit dan tidak memakan waktu yang lama. Mudah dalam memesan menu yang dimaksud adalah tanpa harus mengantri dan tanpa harus menunggu pelayan yang sibuk dengan pelanggan lainnya. Pelanggan restoran juga dapat mengambil waktu dalam memesan pesanan yang sesuai kebutuhan sehingga tidak terganggu dengan keberadaan pelayan yang sedang menunggu pesanan tersebut.

Kemudian pihak restoran membutuhkan sistem yang dapat mengatur dan memanajemen pemesanan menu sesuai dengan kebutuhan pelanggan, juga kebutuhan pihak restoran tersebut. Sistem ini dapat mempermudahkan pihak restoran seperti mengatur antrian pesanan sesuai waktu pemesanan pelanggan, mengatur status ketersediaan menu secara real-time, dan dapat mengkontrol jumlah pesanan.

I.2. Rumusan Masalah

2.1. Bagaimana merancang dan membangun aplikasi pemesanan menu makanan restoran berbasis android.

2.2. Bagaimana merancang dan membangun aplikasi pemesanan menu makanan restoran menggunakan web-service.

I.3. Batasan Masalah

3.1. Penelitian ini mengambil studi kasus pada Taipan Resto Manado.

3.2. Pembuatan aplikasi ini berbasis android dan menggunakan smartphone.

3.3. Pembuatan aplikasi ini dikhususkan pemesanan menu restoran saja.

I.4. Tujuan

Untuk merancang dan membangun aplikasi pemesanan menu makanan restoran berbasis android dan dapat menggunakan web-service.

I.5. Manfaat

Dapat membantu pihak restoran untuk memanajemen sistem pemesanan menu dan agar pelanggan restoran lebih merasa nyaman dan mudah dalam memesan menu restoran.

\section{DASAR TEORI}

\section{II.1. Perancangan Sistem}

Perancangan ${ }^{[1]}$ adalah langkah pertama dalam fase pengembangan rekayasa produk atau sistem. Perancangan itu adalah proses penerapan berbagai teknik dan prinsip yang bertujuan untuk mendefinisikan sebuah peralatan, satu proses atau satu sistem secara detail yang membolehkan dilakukan realisasi fisik. Fase ini adalah inti teknis dari proses rekayasa perangkat lunak. Pada fase ini elemenelemen dari model analisa dikonversikan. Dengan menggunakan satu dari sejumlah metode perancangan, fase perancangan akan menghasilkan perancangan data, perancangan antarmuka, perancangan arsitektur dan perancangan prosedur. 


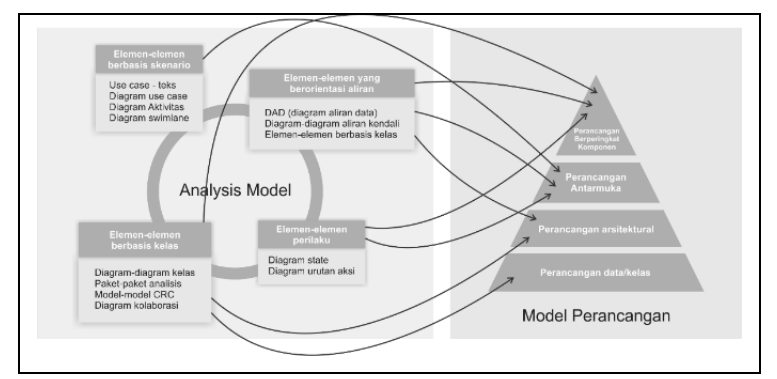

Gambar 2.1 Menerjemahkan model kebutuhan kedalam model perancangan.

\section{II.2. Implementasi Sistem}

Fase implementasi sistem terdiri dari tiga kegiatan, yaitu pemograman, dokumentasi, dan pengujian. Pemograman adalah penciptaan perangkat lunak komputer dengan menggunakan bahasa pemograman. Dokumentasi adalah pencatatan hasil-hasil yang didapat dari fase-fase pengembangan perangkat lunak. Pengujian adalah untuk melihat apakah perangkat lunak yang dibuat dengan bahasa pemograman telah sesuai dengan persoalan.

\section{II.3. Android}

Android adalah sebuah sistem operasi untuk perangkat mobile berbasis linux yang mencakup sistem operasi, middleware dan aplikasi. Android menyediakan platform terbuka bagi para pengembang untuk menciptakan aplikasi mereka. Awalnya, google Inc.membeli android Inc, pendatang baru yang membuat peranti lunak untuk ponsel.

Kelebihan dari android yaitu;

\section{- Complete Platform}

Menyediakan tools yang berguna untuk membangun sebuah aplikasi yang kemudian aplikasi tersebut dapat lebih dikembangkan lagi oleh para developer.

- Open Source Platform

Mudah dikembangkan oleh para developer karena bersifat terbuka.

- Free Platform

Developer dengan bebas bisa mengembangkan, mendistribusikan dan memperdagangkan sistem operasi Android tanpa harus membayar royalty untuk mendapatkan license.

\section{II.4. Apache Cordova}

Apache Cordova atau disebut saja cordova adalah open-source framework untuk pengembangan aplikasi mobile. Yang memungkinkan pengembang menggunakan teknologi web standar seperti HTML5, CSS3, dan JavaScript untuk pengembangan crossplatform. Aplikasi cordova tetap dikemas sebagai paket aplikasi menggunakan Software Development Kit (SDK) dari platform masing-masing. Maksudnya jika paket dijalankan pada android maka pengemasannya harus menggunakan SDK android, demikian pula dengan platform yang lainnya.

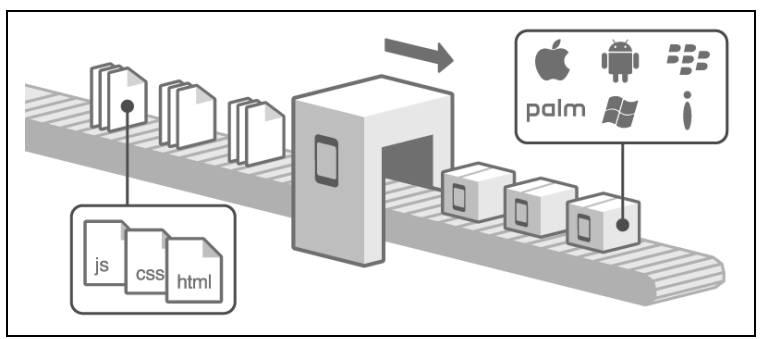

Gambar 2.2 Cara kerja apache cordova.

Cordova merupakan satu set Application Programming Interface (API) perangkat yang memungkinkan pengembang aplikasi mobile untuk mengakses fungsi perangkat asli (native) seperti kamera atau accelerometer dengan menggunakan bahasa javascript. Saat menggunakan API Cordova pengembang dapat membangun aplikasi mobile tanpa kode asli atau pemrograman native (misal: java dan xml untuk android), sebaliknya teknologi yang digunakan adalah teknologi web. Hasilnya adalah sebuah aplikasi web yang berjalan secara local (pada perangkat itu sendiri) tidak seperti layaknya web pada umumnya yang berjalan diserver secara terpisah.

\section{II.5. Ionic Framework}

Ionic Framework adalah kerangka kerja yang dibangun untuk mengembangan aplikasi hybridmobile dengan menggunakan teknologi web. Ionic menyediakan komponen-komponen mobile seperti button, header-footer, cards, dan lain sebagainya kemudian menyediakan css standar dan menggunakan javascript untuk menjalankan fungsi-fungsi aplikasi, untuk javascript sendiri ionic memakai teknologi angular.js.

\section{METODOLOGI}

\section{III.1. Pengertian RAD}

Rapid Application Development (RAD) ${ }^{[2]}$. Adalah salah satu metode pengembangan suatu sistem informasi dengan waktu yang relatif singkat. Untuk pengembangan suatu sistem informasi yang normal membutuhkan waktu minimal 180 hari, akan tetapi dengan menggunakan metode RAD suatu sistem dapat diselesaikan hanya dalam waktu 30-90 hari.

Tujuan utama dari semua metode sistem development adalah memberikan suatu sistem yang dapat memenuhi harapan dari para pemakai, akan tetapi sering kali di dalam melakukan pengembangan suatu sistem tidak melibatkan para pemakai sistem secara langsung, sehingga hal ini menyebabkan sistem informasi yang dibuat jauh dari harapan pemakai yang dapat berakibat sistem tersebut walaupun dapat diterima tetapi para pemakai enggan untuk menggunakannya atau bahkan para pemakai menolak untuk menggunakannya.

Pada saat RAD diimplementasikan, maka para pemakai bisa menjadi bagian dari keseluruhan proses 
pengembangan sistem dengan bertindak sebagai pengambil keputusan pada setiap tahapan pengembangan. RAD bisa menghasilkan suatu sistem dengan cepat karena sistem yang dikembangkan dapat memenuhi keinginan dari para pemakai sehingga dapat mengurangi waktu untuk pengembangan ulang setelah tahap implementasi. (Agustinus, 2002).

\section{III.2. Tahapan-tahapan RAD}

Dalam metode RAD terdapat langkah - langkah yang dibagi dalam empat fase. Langkah-langkah metode RAD adalah sebagai berikut:

1. Fase 1: Analisa Persyaratan.

Fase Analisa Persyaratan merupakan proses melakukan pengumpulan data atau bahan dan mengidentifikasi layanan, batasan, dan obyektivitas dari pengumpulan daya yang dilakukan.

Hasil atau Output dari proses ini berupa laporan penelitian dari pengembangan aplikasi, analisis spesifikasi awal, analisis persyaratan user dan sistem, dan informasi fitur pada aplikasi pemesanan menu restoran. Dalam proses ini sumber daya yang digunakan yaitu komputer dan handphone dengan koneksi internet, buku literatur dan user sebagai responden untuk mengetahui respon terhadap aplikasi pemesanan menu restoran yang akan dikembangkan. Berikut tahapan-tahapan pada fase ini:

\section{Fase 2: Analisis Modeling.}

Fase berikutnya adalah fase analisis model yang bertujuan menganalisis semua kegiatan dalam arsitektur sistem secara keseluruhan dengan cara identifikasi dan abstraksi sistem yang mendasar. Yang mana proses yang dilakukan dimulai dari mengidentifikasi aktor dan use case dengan merancang aplikasi yang akan dikembangkan, menggambarkan aliran control untuk mengetahui hubungan aktor dan objek, menggambarkan komunikasi antar objek dan aktor, menggambarkan perubahan keadaan suatu objek pada aplikasi kelas tertentu, memodelkan prilaku use case serta objek pada aplikasi dan menggambarkan perubahan suatu objek pada kelas tertentu.

Masukan pada tahapan ini yaitu informasi aplikasi pada penelitian sebelumnya, data - data hasil dari tahapan Fase 1: Analisis Persyaratan dan metode yang akan digunakan pada fase berikutnya.

Tabel 3.1 Daftar aktor beserta tugas dan tanggungjawabnya.

\begin{tabular}{|c|c|}
\hline Aktor & Tugas dan Tanggung Jawab \\
\hline Admin & $\begin{array}{l}\text { 1. Mengatur menu-menu restoran } \\
\text { Taipan, berupa penambahan data, edit } \\
\text { data, dan hapus data }\end{array}$ \\
\hline
\end{tabular}

\begin{tabular}{|l|l|}
\hline & $\begin{array}{l}\text { 2. } \text { Mengatur meja-meja restoran Taipan } \\
\text { dalam memberikan kode meja pada } \\
\text { pelanggan. }\end{array}$ \\
& $\begin{array}{l}\text { 3. Memberikan daftar pesanan } \\
\text { pelanggan kepada pihak dapur. }\end{array}$ \\
& 4. Mencetak Struk/Tagihan pelanggan \\
\hline User & $\begin{array}{l}\text { 1. Melihat daftar menu restoran Taipan } \\
\text { 2. Melihat informasi restoran Taipan }\end{array}$ \\
& $\begin{array}{l}\text { 3. Memesan menu restoran Taipan } \\
\text { 4. Melihat daftar pesanan dan total } \\
\text { tagihan }\end{array}$ \\
\hline
\end{tabular}

3. Fase 3: Desain Modeling.

Pada fase desain modeling aplikasi pemesanan menu restoran dikembangkan berdasarkan analisis yang dilakukan pada fase analisis modeling sebelumnya. Pada tahapan analisis dan desain modeling mengalami perulangan bertujuan untuk medapatkan hasil perancangan sistem yang benar-benar memenuhi kebutuhan. Hasil dari fase ini adalah basis data, antarmuka dan spesifikasi desain.

a. Use Case Diagram.

1. Use case pelanggan.

Use Case $^{[5]}$ pada client-side (Aplikasi Android), dimana data berasal dari Server diakses oleh Aplikasi Android menggunakan Web Service, data tersebut merupakan database berisi daftar menu, dan nantinya Client akan mengirim data pemesanan menu ke Server melalui Web Service.

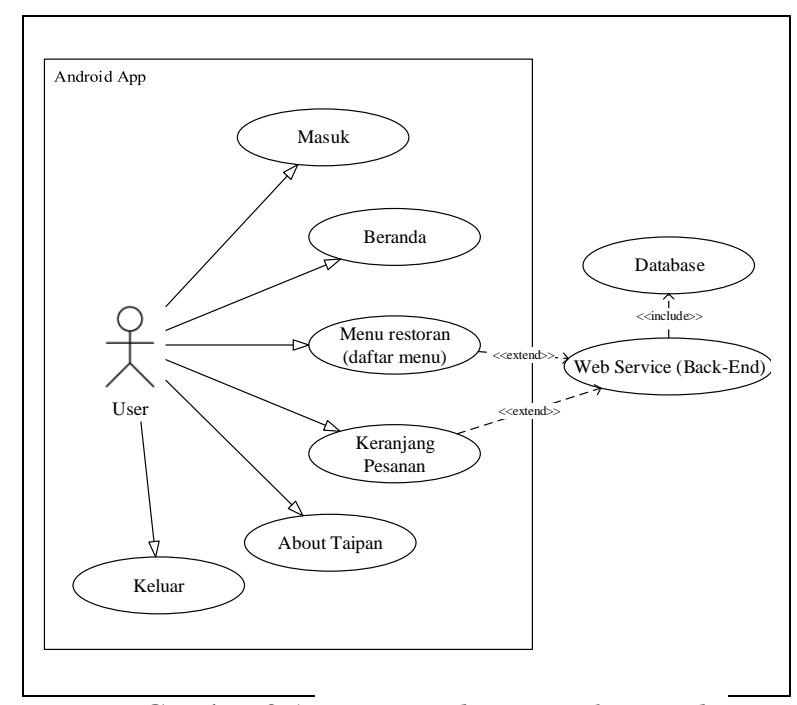

Gambar 3.1 Use case diagram client-side.

2. Use case admin.

Pada gambar 3.2 dibawah ini menjelaskan Use Case ${ }^{[5]}$ pada sisi Back-End (Web Application). Admin dapat menambah daftar menu, mengupdate menu, dan menghapus menu, mengatur kode meja kemudian Admin juga dapat melihat daftar pesanan dari Client-side. 


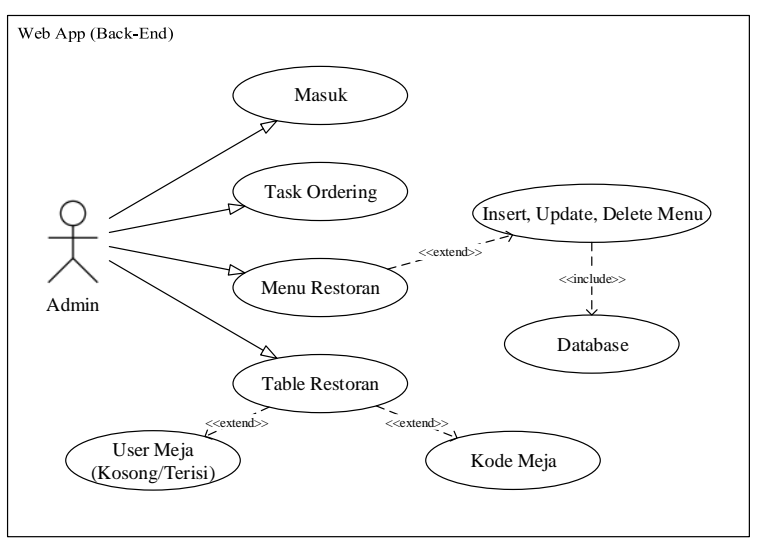

Gambar 3.2 Use case diagram server-side.

b. Data Flow Diagram.

Pada sitem pemesanan menu restoran ${ }^{[4]}$ terdapat 2 terminator (external interactor) yang menggunakan sistem ini yaitu pelanggan dan admin dimana pelanggan melakukan pemesanan menu ke sistem melalui aplikasi android sedangkan admin melakukan manajemen pemesanan ke sistem dalam melalui aplikasi web. Dapat dilihat pada gambar 3.3 di bawah ini:

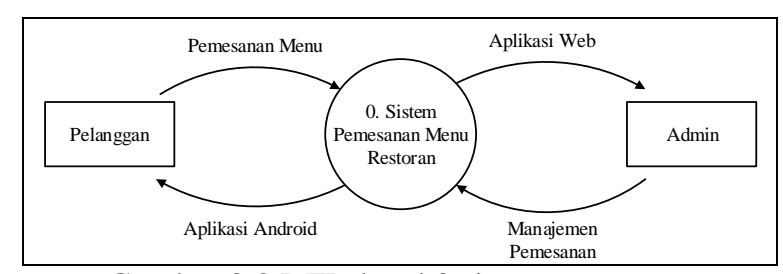

Gambar 3.3 DFD level 0 sistem pemesanan menu.

Sistem pemesanan menu ${ }^{[4]}$ terbagi menjadi dua antarmuka dengan masing-masing proses. Pelanggan melakukan pemesanan sedangkan admin melakukan manajemen dari pemesanan tersebut, admin juga berperan penting dalam menyediakan web service agar pelanggan dapat meluakukan pemesanan admin juga melakukan query database berupa penambahan, pengubahan dan penhapusan data yang dapat di jelaskan melalui DFD level 1 pada gambar berikut ini:

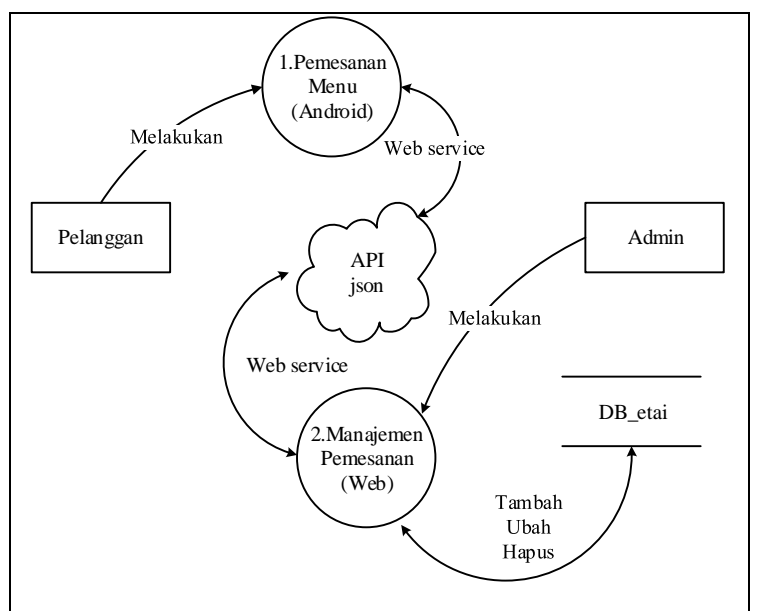

Gambar 3.4 DFD Level 1 sistem pemesanan menu.

c. Desain Antarmuka.

Pada tahap selanjutnya adalah tahap merancang antarmuka untuk aplikasi yang akan dibangun, antarmuka ini bersifat sementara atau merupakan acuan, kedepannya saat pengimpelentasi antarmuka ini bisa saja terjadi perubahan sesuai kubutuhan.

\section{Fase 4: Konstruksi}

Pada fase konstruksi ini merupakan tahapan pembuatan aplikasi yang mengacuh pada tahapan sebelumnya dimana untuk menunjukan platform, hardware dan software yang digunakan serta batasan dalam implementasi dan menguji performansi dari aplikasi yang dikembangkan. Beberapa tahapan dalam fase ini yang akan di jelaskan pada bab selanjutnya yaitu:

- Lingkungan Implementasi Penerapan sistem pada hardware yang digunakan.

- Implementasi Basis Data Penerapan database yang digunakan.

- Melakukan Pemrograman Menulis kode sumber program dengan bahasa pemrograman yang digunakan diantaranya HTML, CSS, JavaScript, PHP dan lain-lain.

- Implementasi Antarmuka Penerapan sistem yang dikaji dengan menampilkan antarmuka aplikasi.

- Pengujian

Penerapan black-box testing pada sistem untuk berusaha menemukan kesalahan seperti kesalahan antarmuka, kesalahan input-output, kesalahan kinerja, kesalahan dalam basis data atau kesalahan fungsifungsi yang tidak benar.

\section{HASIL PENELITIAN}

IV.1. Lingkungan Implementasi.

Pada hasil penelitian ini, rancangan bangun aplikasi pemesanan menu restoran ${ }^{[6]}$ diimplementasikan pada 
smartphone berplatform android dan personal computer (PC) dengan beberapa browser terinstall berikut penjelasan spesifik dari smartphone dan $\mathrm{pc}$ tersebut:

a. Lingkungan implementasi aplikasi android Tabel berikut adalah penerapan aplikasi pelanggan eTaipan Resto berbasis android.

Tabel 4.1 Lingkungan implementasi client

\begin{tabular}{|l|l|l|}
\hline Perangkat & \multicolumn{2}{|c|}{ Spesifikasi Perangkat } \\
\hline & Hardware & Software \\
\cline { 2 - 3 } Asus & Tipe: & OS Versi: 5.0 \\
Zenfone 5 & ASUS_T00J & (Lollipop) \\
& Dimensi: & \\
& $5.83 \quad$ x 2.87 x & \\
& 0.41 inc & \\
\hline
\end{tabular}

b. Lingkungan implementasi aplikasi web-admin Tabel berikut adalah penerapan aplikasi admin Taipan Server berbasis web.

Tabel 4.2 Lingkungan implementasi server

\begin{tabular}{|l|l|l|}
\hline \multicolumn{1}{|c|}{ Perangkat } & \multicolumn{2}{|c|}{ Spesifikasi } \\
\hline \multirow{3}{*}{$\begin{array}{l}\text { Personal } \\
\text { Computer }\end{array}$} & Hardware & Software \\
\cline { 2 - 3 } & & OS Versi: \\
& & Win 10 \\
& & Enterprise 64bit \\
\hline
\end{tabular}

\begin{tabular}{|l|l|l|}
\hline & HP (Hewlett- & Browser: \\
Packard) 610- & Google Chrome, \\
1178d & Microsoft Edge, \\
Processor: & Opera \\
Intel ${ }^{\circledR}$ Core \\
i5 & Developer, \\
& Memory: & \\
4GB & \\
\hline
\end{tabular}

IV.2. Implementasi Basis Data.

Dalam rancang bagun aplikasi ini peneliti menggunakan server XAMPP dan database ${ }^{[3]}$ MySQL dengan nama database db_etai dan beberapa tabel, dalam memanejemen database menggunakan phpMyAdmin yang dapat dilihat pada gambar 4.1 dibawah ini:

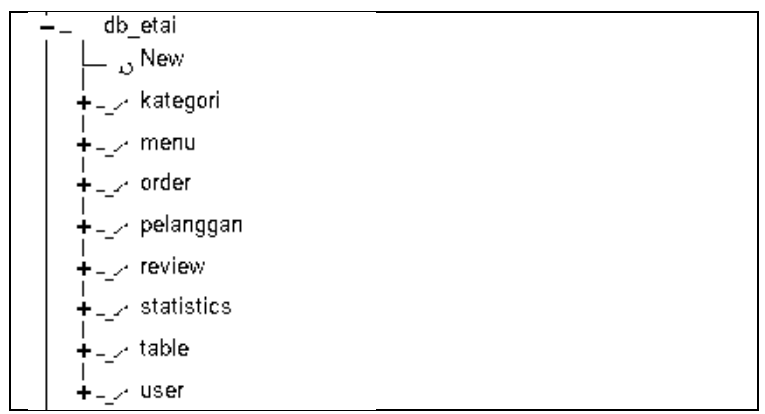

Gambar 4.1 Penerapan database mysql.

Gambar 4.2 dibawah ini menujukan class diagram ${ }^{[5]}$ [3] $^{[3}$ gan relasi pada database:

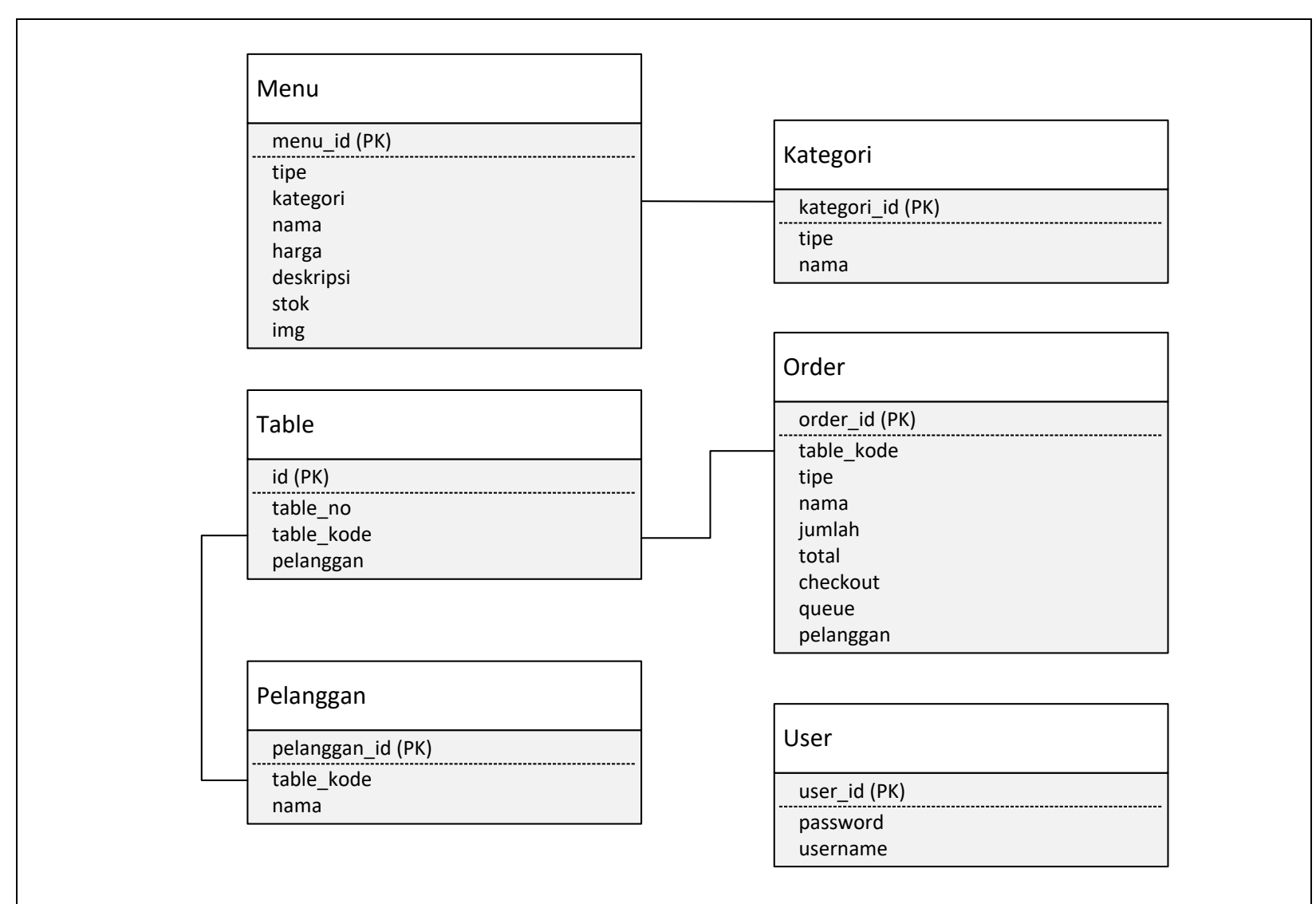


IV.3. Implementasi Antarmuka.

4.1. Antarmuka Aplikasi Android (Client)

Berikut ini adalah penjelasan mengenai menerapan antarmuka aplikasi eTaipan Resto berbasis android, pertama-tama user (pelanggan) membuka aplikasi terinstall pada daftar aplikasi seperti pada gambar dibawa ini:

a. Tampilan Login

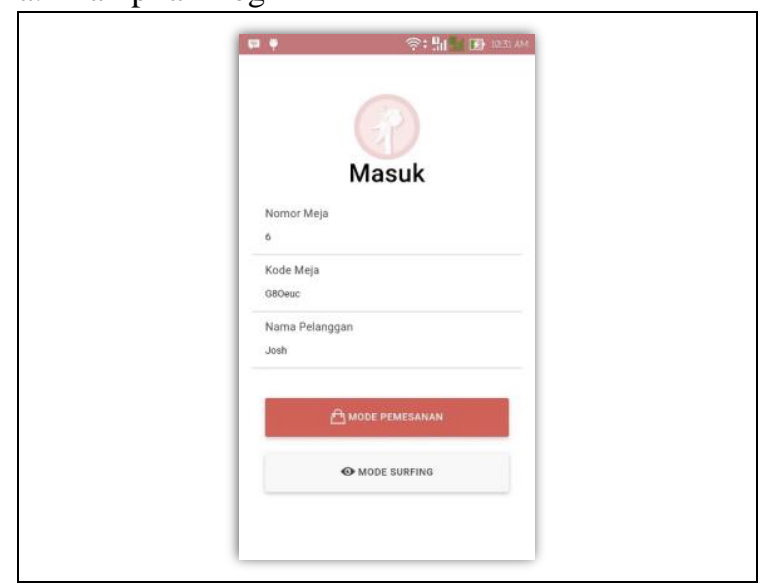

Gambar 4.3 Login

b. Tampilan Beanda

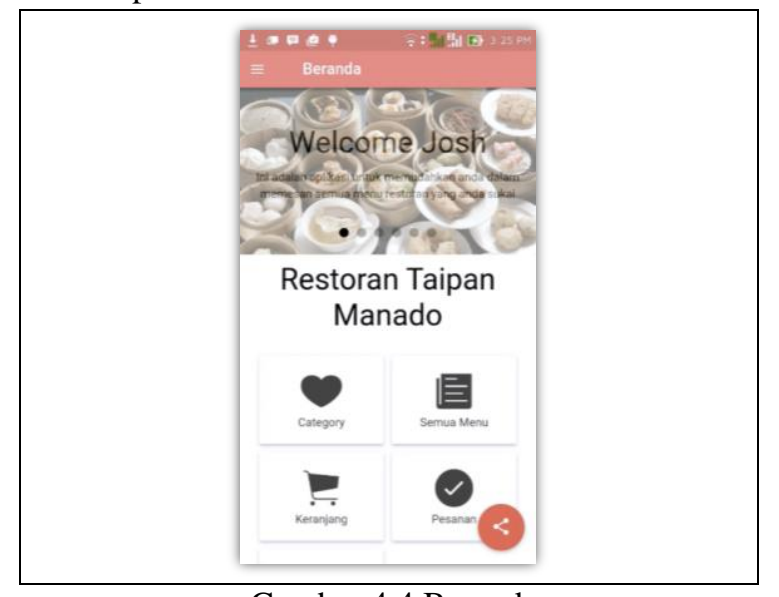

Gambar 4.4 Beranda

c. Tampilan Menu Restoran

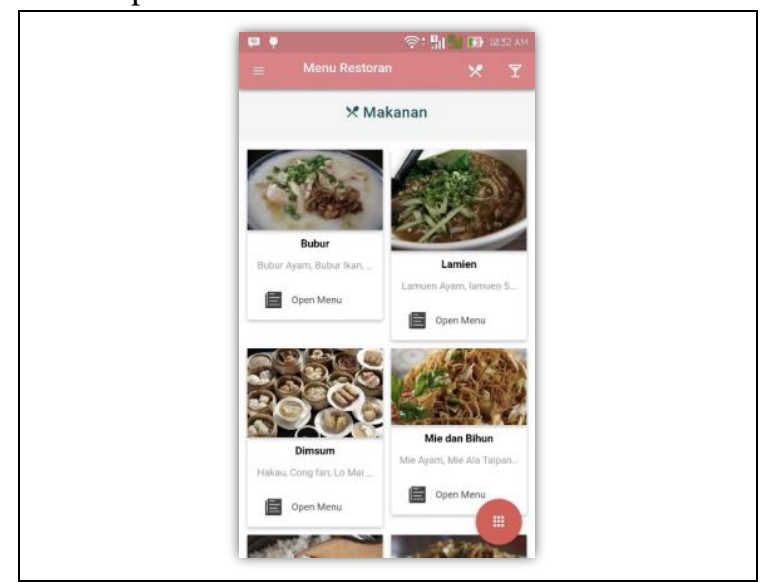

Gambar 4.5 Menu Restoran d. Tampilan Daftar Menu Berdasarkan Kategori

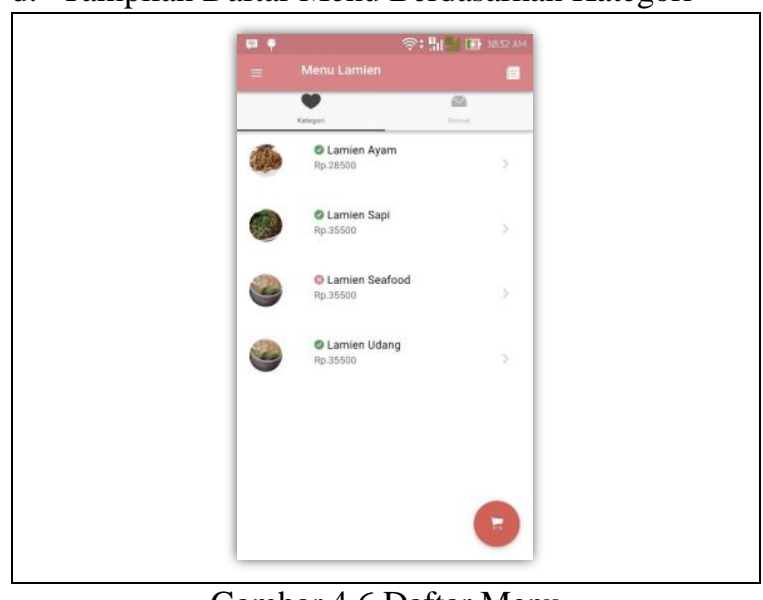

Gambar 4.6 Daftar Menu

e. Tampilan Detail Menu

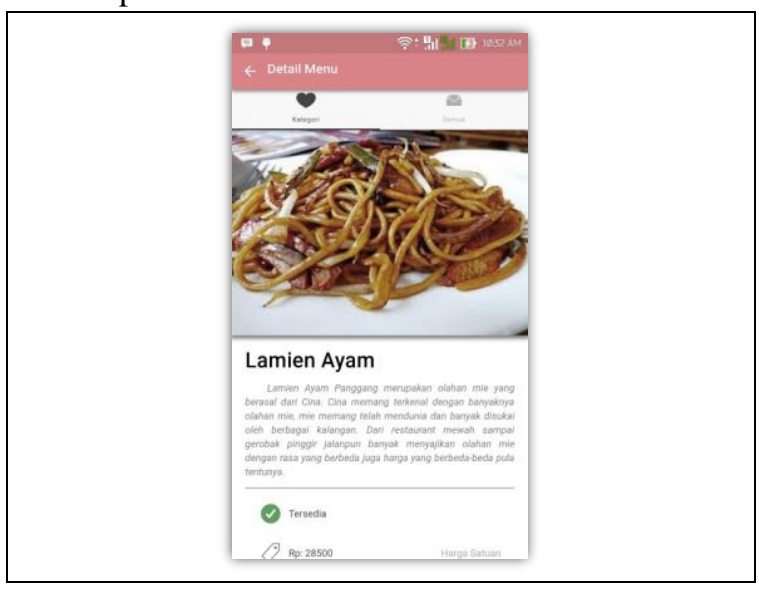

Gambar 4.7 Detail Menu

f. Tampilan Keranjang Pesanan

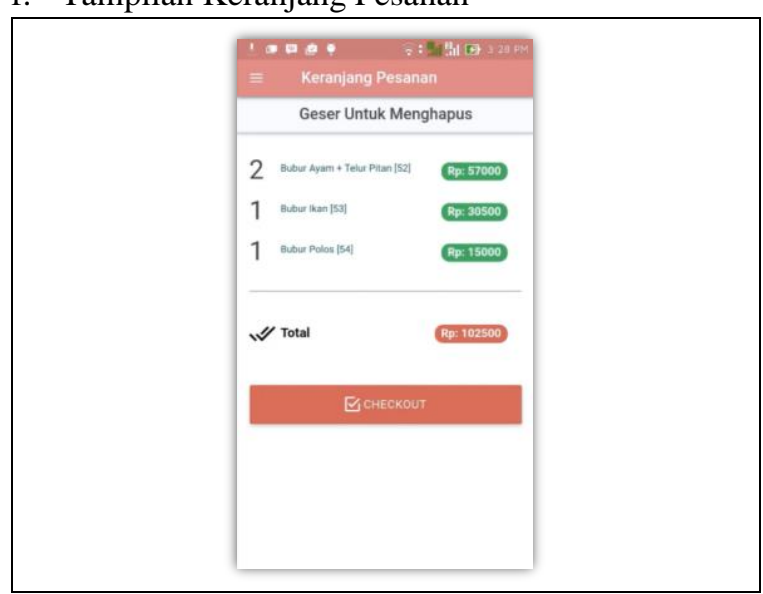

Gambar 4.8 Keranjang Pesanan 
g. Tampilan Pesanan Saya

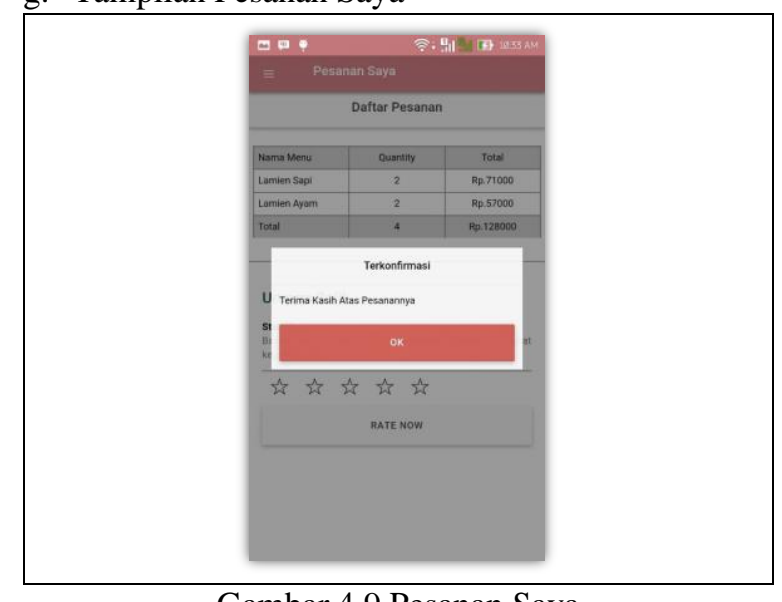

Gambar 4.9 Pesanan Saya

h. Tampilan Hubungi Kami

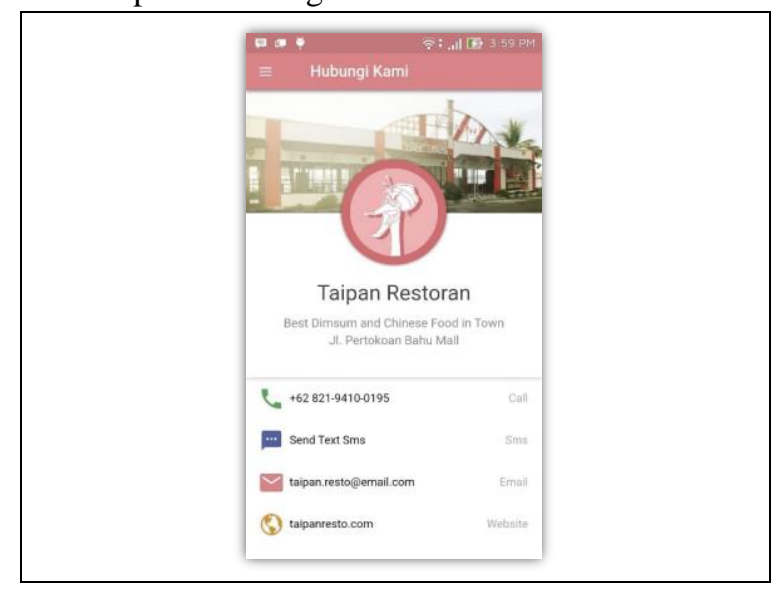

Gambar 4.10 Hubungi Kami

i. Tampilan Logout

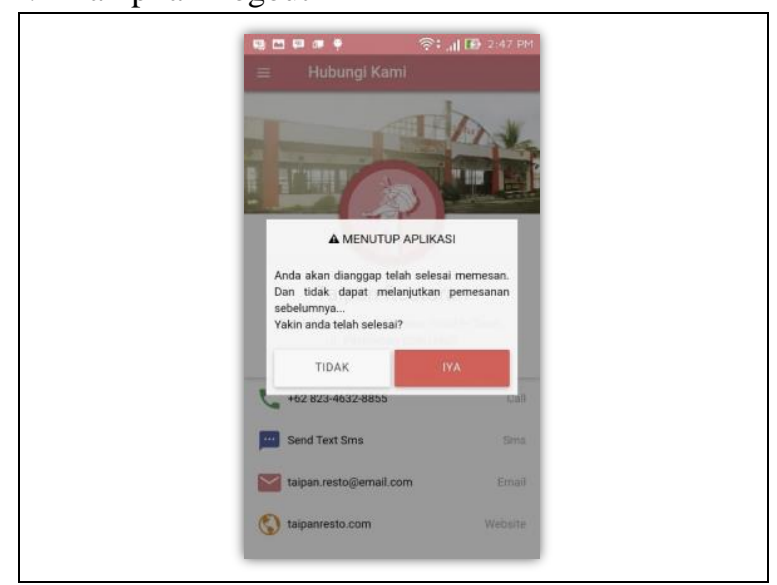

Gambar 4.11 Logout

\subsection{Antarmuka Aplikasi Web-admin (Server)}

Dibawah ini menjelaskan setiap tampilan yang ada pada aplikasi berbasis website. a. Tampilan Login Admin

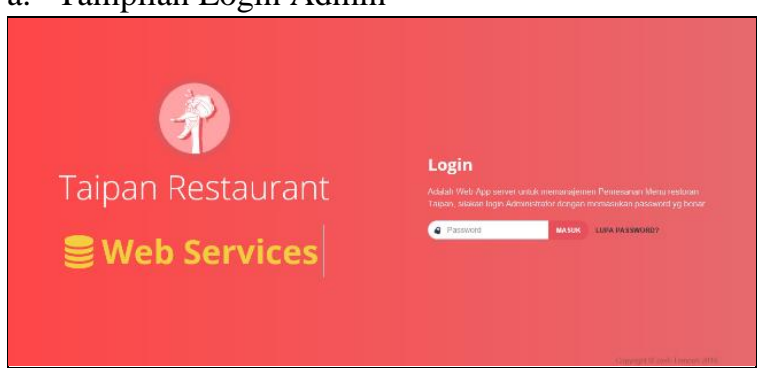

Gambar 4.12 Login Admin

b. Tampilan Dashboard Admin

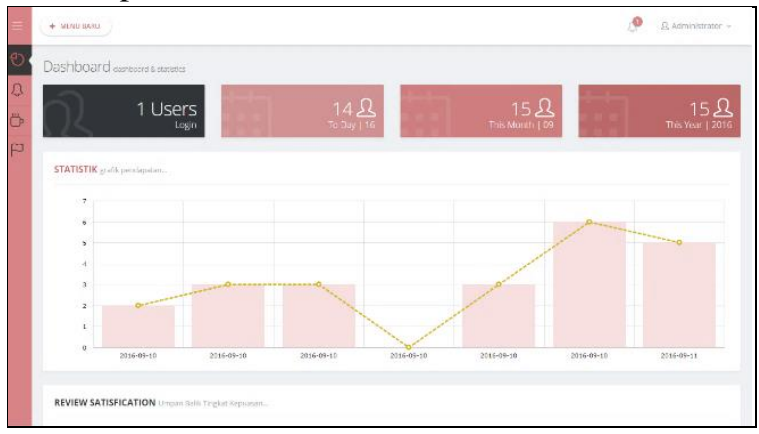

Gambar 4.13 Dashboard Admin

c. Tampilan Task Ordering Admin

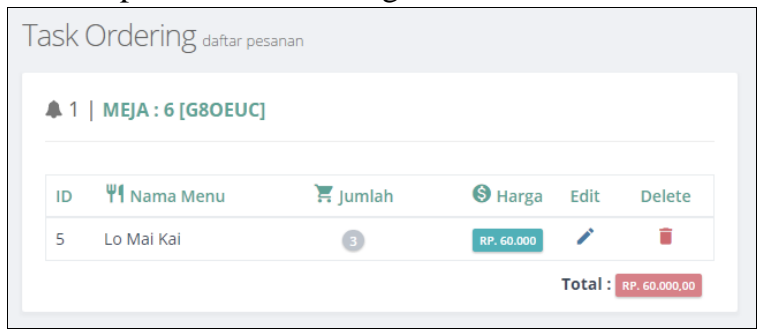

Gambar 4.14 Task Ordering Admin

d. Tampilan Menu Restoran Admin

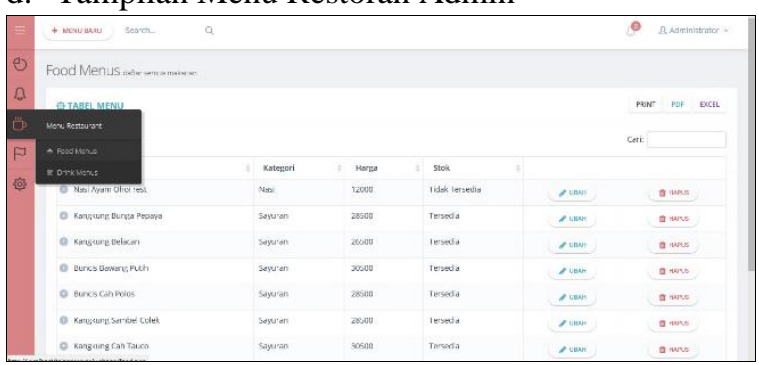

Gambar 4.15 Menu Restoran Admin

e. Tampilan Meja Restoran Admin

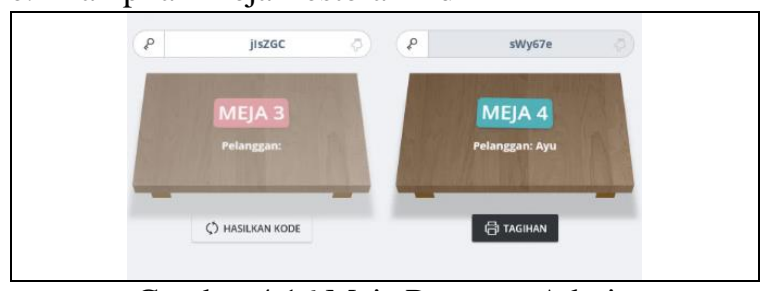

Gambar 4.16 Meja Restoran Admin 


\section{f. Tampilan Struk Pesanan}

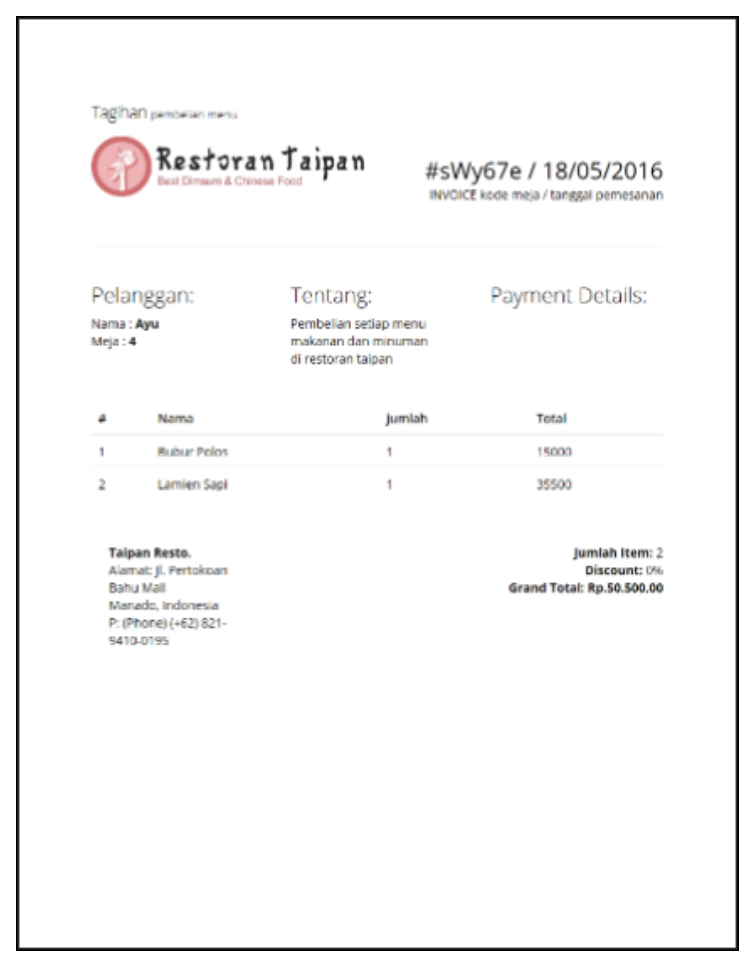

Gambar 4.17 Struk Pesanan

\section{IV.4. Pengujian.}

Pada tahap pengujian sistem pemesanan menu restoran ini hanya diterapkan pada pengujian blackbox. Pengujian dilakukan pada dua aplikasi android dan web, untuk android dijalankan pada perangkat Asus Zenfone 5 dan untuk web dijalankan pada browser Google Chrome. Untuk penjelasan hasil pengujian yang dilakukan dapat dilihat pada tabel pengujian dibawah ini:

\subsection{Pengujian Aplikasi Android (Client)}

Tabel 4.3 Tabel pengujian aplikasi android.

\begin{tabular}{|c|c|}
\hline No & Titik Pemeriksaan \\
\hline \multirow{4}{*}{1.} & Testing Masuk \\
\hline & $\begin{array}{l}\text { Apakah aplikasi dapat menghandle ketika } \\
\text { tidak dapat terkoneksi internet? }\end{array}$ \\
\hline & $\begin{array}{l}\text { Apakah kode meja, nomor meja dan username } \\
\text { sudah dapat dibaca oleh sistem? }\end{array}$ \\
\hline & $\begin{array}{l}\text { Apakah sistem dapat membatasi inputan, } \\
\text { melihat meja yang terisi dan mengetahui } \\
\text { nomor meja dan kode meja tidak cocok? }\end{array}$ \\
\hline \multirow{3}{*}{2.} & Testing fungsi mode aplikasi \\
\hline & $\begin{array}{l}\text { Apakah aplikasi dapat membedahkan mode } \\
\text { pemesanan dan mode surfing? }\end{array}$ \\
\hline & $\begin{array}{l}\text { Apakah aplikasi akan menampilkan tombol } \\
\text { pesanan atau tidak? }\end{array}$ \\
\hline \multirow{3}{*}{3.} & Testing fungsi menginput quantity \\
\hline & $\begin{array}{l}\text { Apakah nilai banyaknya item sudah } \\
\text { ditetapkan dan dapat diubah? }\end{array}$ \\
\hline & Apakah nilai banyaknya item dibatasi? \\
\hline 4. & Testing fungsi tambah pesanan \\
\hline
\end{tabular}

\begin{tabular}{|c|c|}
\hline No & Titik Pemeriksaan \\
\hline & $\begin{array}{l}\text { Apakah sistem dapat menambah data } \\
\text { pesanan? }\end{array}$ \\
\hline \multirow[b]{2}{*}{5.} & Testing fungsi hapus pesanan \\
\hline & $\begin{array}{l}\text { Apakah sistem dapat mengahapus data } \\
\text { pesanan? }\end{array}$ \\
\hline \multirow{3}{*}{6.} & Testing memuat menu \\
\hline & $\begin{array}{l}\text { Apakah sistem dapat memuat menu restoran } \\
\text { sesuai pilihan? }\end{array}$ \\
\hline & $\begin{array}{l}\text { Apakah sistem dapat memuat data menu } \\
\text { dengan cepat? }\end{array}$ \\
\hline \multirow[b]{2}{*}{7.} & Testing fungsi checkout \\
\hline & $\begin{array}{l}\text { Apakah sistem dapat mengkonfirmasi } \\
\text { pesanan dengan benar? }\end{array}$ \\
\hline \multirow{3}{*}{8.} & Testing kondisi ketersediaan menu \\
\hline & $\begin{array}{l}\text { Apakah sistem menampilkan status } \\
\text { ketersediaan menu sudah sesuai? }\end{array}$ \\
\hline & $\begin{array}{l}\text { Apakah sistem tidak menampilkan tombol } \\
\text { tambah pesanan jika status ketersediaan = } \\
\text { flase? }\end{array}$ \\
\hline \multirow{3}{*}{9.} & Testing keluar \\
\hline & $\begin{array}{l}\text { Apakah sistem menampilkan konfirmasi } \\
\text { pertanyaan menutup aplikasi? }\end{array}$ \\
\hline & $\begin{array}{l}\text { Apakah sistem menampilkan halaman masuk } \\
\text { setelah keluar berhasil? }\end{array}$ \\
\hline
\end{tabular}

4.2. Pengujian Aplikasi Web-admin (Server)

Tabel 4.4 Tabel pengujian aplikasi web-admin

\begin{tabular}{|c|c|}
\hline No & Titik Pemeriksaan \\
\hline \multirow{5}{*}{1.} & Testing Masuk \\
\hline & $\begin{array}{l}\text { Apakah terdapat error saat membuka halaman } \\
\text { masuk? }\end{array}$ \\
\hline & $\begin{array}{l}\text { Apakah password sudah dapat dibaca oleh } \\
\text { sistem dan tidak menerima form kosong? }\end{array}$ \\
\hline & $\begin{array}{l}\text { Apakah sistem dapat menampilkan pesan } \\
\text { error? }\end{array}$ \\
\hline & $\begin{array}{l}\text { Apakah aplikasi dapat mengakses halaman } \\
\text { lain tanpa melakukan login? }\end{array}$ \\
\hline \multirow[b]{2}{*}{2.} & Testing Dashboard \\
\hline & $\begin{array}{l}\text { Apakah halaman dashboard berjalan dengan } \\
\text { baik? }\end{array}$ \\
\hline \multirow{3}{*}{3.} & Testing Task Ordering \\
\hline & $\begin{array}{l}\text { Apakah halaman task ordering berjalan } \\
\text { dengan baik? }\end{array}$ \\
\hline & $\begin{array}{l}\text { Apakah halaman dapat memuat data } \\
\text { pemesanan dengan baik dan cepat? }\end{array}$ \\
\hline \multirow[b]{2}{*}{4.} & Testing fungsi tambah data \\
\hline & $\begin{array}{l}\text { Apakah sistem dapat menambah data menu } \\
\text { baru dengan baik? }\end{array}$ \\
\hline \multirow[b]{2}{*}{5 . } & Testing fungsi ubah data \\
\hline & $\begin{array}{l}\text { Apakah sistem dapat mengubah data menu } \\
\text { dengan baik? }\end{array}$ \\
\hline \multirow[b]{2}{*}{6.} & Testing fungsi hapus data \\
\hline & $\begin{array}{l}\text { Apakah sistem dapat menghapus data menu } \\
\text { dengan baik? }\end{array}$ \\
\hline 7. & Testing halaman menu \\
\hline
\end{tabular}




\begin{tabular}{|c|c|}
\hline No & Titik Pemeriksaan \\
\hline & $\begin{array}{l}\text { Apakah halaman menu restoran berjalan } \\
\text { dengan baik? }\end{array}$ \\
\hline & $\begin{array}{l}\text { Apakah fitur pencarian, shorting dan paging } \\
\text { berjalan dengan baik? }\end{array}$ \\
\hline \multirow{4}{*}{8.} & Testing halaman table restoran \\
\hline & $\begin{array}{l}\text { Apakah halaman table restoran berjalan } \\
\text { dengan baik? }\end{array}$ \\
\hline & $\begin{array}{l}\text { Apakah sistem dapat menampilkan meja yang } \\
\text { terisi dan meja yang kosong? }\end{array}$ \\
\hline & $\begin{array}{l}\text { Apaka sistem manmpilkan kode meja dan } \\
\text { dapat mengubah kode meja? }\end{array}$ \\
\hline \multirow{3}{*}{9.} & Testing fungsi cetak tagihan \\
\hline & $\begin{array}{l}\text { Apakah sistem menampilkan struk tagihan } \\
\text { kemudian dapat dicetak? }\end{array}$ \\
\hline & $\begin{array}{l}\text { Apakah sistem dapat menyelesaikan proses } \\
\text { pemesanan ketika mencetak tagihan? }\end{array}$ \\
\hline \multirow{2}{*}{10.} & Testing Keluar Web-admin \\
\hline & $\begin{array}{l}\text { Apakah fungsi keluar dapat berjalan dengan } \\
\text { baik? }\end{array}$ \\
\hline
\end{tabular}

\section{PENUTUP}

\section{V.1. Kesimpulan}

Dalam rancang bangun aplikasi pemesanan menu restoran berbasis android ini dikembangkan menggunakan teknologi web dengan memanfaatkan framework cordova sebagai cross-platform dan framework ionic. Kedua framework tersebut dapat membangun aplikasi ini dengan baik dan cepat.

Dengan menggunakan web-services aplikasi pemesanan menu restoran dapat saling terintegrasi dalam sistem pememesanan, dimana aplikasi android sebagai client untuk memesan dan aplikasi web-admin sebagai server untuk menampung pesanan dari client.

\section{V.2. Saran}

Untuk mengembangkan aplikasi android crossplatform perlu pelajari dan diperdalam beberapa model framework pendukung cordova. Dalam menggunakan framework ionic versi 2.0 yang banyak digunakan saat ini adalah lebih mudah untuk menggunakan typescript dibandingkan javascript.

Aplikasi pemesanan menu restoran kedepannya dapat dikembangkan lebih baik lagi seperti adanya penambahan fitur antara lain fitur pembayaran.

\section{DAFTAR PUSTAKA}

[1] Roger S.Pressman,Software Engineering. Edisi 7 : Pendekatan Praktisi Tujuh, 2010

[2] Neourtjayana Agustinus. 2002. "Studi Analisis Rapid Application Development sebagai salah satu alternatif metode pengembang peragkat lunak". Fakultas teknologi industry.Bandung.
[3] Lu Gojon. 1963. Multimedia database management systems. Artech Hous Computing Liblary. Boston London.

[4] Muchtar Januar. 2009. Penentuan jalur efektif pola Data Flow Diagram (DFD) Dengan metode structural equation modeling (SEM) Di PT. anugrah Kurnia Pusaka. Universitas Sumatra Utara. Medan.

[5] Bayu Aji. 2011. "UML". 29 Januari 2015. bayuaji.staff.gunadarma.ac.id

[6] Hansun Seng.2013."'Rancang Bangun ClientSide Mobile Web App Menggunakan JQuery Mobile".Tanggerang.

\section{RIWAYAT PENULIS}

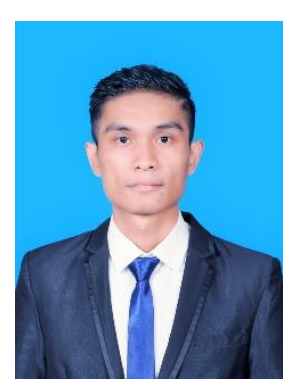

Nama lengkap Jos Forman Tompoh, lahir pada tanggal 4 juni tahun 1992 di kota Tobelo kab. Halmahera Utara prov. Maluku Utara. Anak ke-5 dari lima bersaudara. Dengan pendidikan SD Negeri 2 Tobelo, SMP Negeri 1 Tobelo, SMA Kristen Tobelo, dan pada tahun 2011 melanjutkan sekolah ke Perguruan tinggi di Universitas Sam Ratulangi dan mengambil Jurusan Teknik Informatika. Pada tahun 2016 penulis lulus dengan menyelesaikan penulisan penelitian tugas akhir sebagai salah satu syarat untuk mendapatkan gelar sarjana (S1), dengan judul skripsi "Rancang Bangun Aplikasi Pemesanan Menu Makanan Restoran Berbasis Android" yang dibimbing oleh dua dosen pembimbing yaitu Dr. Eng Steven Sentinuwo, ST, MT. dan Alicia Sinsuw, ST., MT. 